\title{
Ginkgolic acid inhibits the invasiveness of colon cancer cells through AMPK activation
}

\author{
LINA QIAO, JIANBAO ZHENG, XIANZHEN JIN, GUANGBING WEI, \\ GUANGHUI WANG, XUEJUN SUN and XUQI LI
}

Department of General Surgery, The First Affiliated Hospital of Xi'an Jiaotong University, Xi'an, Shaanxi 710061, P.R. China

Received May 19, 2016; Accepted July 20, 2017

DOI: 10.3892/ol.2017.6967

\begin{abstract}
Tumor cell invasion and metastasis are important processes in colorectal cancer that exert negative effects on patient outcomes; consequently, a prominent topic in the field of colorectal cancer study is the identification of safe and affordable anticancer drugs against cell invasion and metastasis, with limited side effects. Ginkgolic acid is a phenolic acid extracted from ginkgo fruit, ginkgo exotesta and ginkgo leaves. Previous studies have indicated that ginkgolic acid inhibits tumor growth and invasion in a number of types of cancer; however, limited studies have considered the effects of ginkgolic acid on colon cancer. In the present study, SW480 colon cancer cells were treated with a range of concentrations of ginkgolic acid; tetrazolium dye-based MTT, wound-scratch and transwell migration assays were performed to investigate the effects on the proliferation, migration and invasion of colon cancer cells, and potential mechanisms for the effects were explored. The results indicated that ginkgolic acid reduced the proliferation and significantly inhibited the migration and invasion of SW480 cells in a concentration-dependent manner. Additional experiments indicated that ginkgolic acid significantly decreased the expression of invasion-associated proteins, including matrix metalloproteinase (MMP)-2, MMP-9, urinary-type plasminogen activator and $\mathrm{C}-\mathrm{X}-\mathrm{C}$ chemokine receptor type 4, and activated adenosine monophosphate activated protein kinase (AMPK) in SW480 cells. Small interfering RNA silencing of AMPK expression reversed the effect of ginkgolic acid on the expression of invasion-associated proteins. This result suggested that ginkgolic acid inhibited the proliferation, migration and invasion of SW480 colon cancer cells by inducing AMPK activation and inhibiting the expression of invasion-associated proteins.
\end{abstract}

Correspondence to: Dr Xuqi Li, Department of General Surgery, The First Affiliated Hospital of Xi'an Jiaotong University, 277 West Yanta Road, Xi'an, Shaanxi 710061, P.R. China E-mail: lixuqi@163.com

Key words: ginkgolic acid, adenosine 5'-monophosphate-activated protein kinase, colorectal cancer, cell invasion, C-X-C chemokine receptor 4

\section{Introduction}

Colorectal cancer is one of the most common types of malignant cancer worldwide (1). Worldwide, colorectal cancer ranks third among malignant tumor types in morbidity and mortality for male and female populations (2). In China, with the continuous improvement of living standards and changes in dietary habits, the morbidity of colorectal cancer is also increasing (3). At present, surgery remains the primary treatment for colorectal cancer, and the majority of patients experience tumor relapse and/or metastasis (4). Postoperative colorectal cancer liver metastasis is the leading cause of mortality (5). Postoperative chemotherapy has improved survival rates, but the use of chemotherapy drugs is constrained by their side effects $(6,7)$. Therefore, an important topic in the field of colorectal cancer study is the identification of safe and affordable antitumor drugs with minor side effects.

Ginkgo biloba L., also known as ginkgo, is the oldest existing seed plant (8) and is widely distributed in China. Ginkgolic acid is a phenolic acid (a 6-alkyl or 6-alkenyl derivative of salicylic acid) that has been identified in ginkgo fruit, ginkgo exotesta, and ginkgo leaves (9). It has several monomer structures, and the monomers C13:0, C15:0, and C17:1 demonstrate antitumor activity (10). Several previous studies have indicated that ginkgolic acid inhibits tumor growth and invasion in a number of cancer types, including pancreatic, liver, laryngeal and breast cancer (11-13). However, to the best of our knowledge, no studies have been conducted to investigate the effects of ginkgolic acid on colon cancer cells.

Adenosine 5'-monophosphate activated protein kinase (AMPK), a serine/threonine protein kinase, is an intracellular energy sensor (14). Activating the AMPK pathway may be an important mechanism for the antitumor effects of ginkgolic acid (11). Epidemiological data demonstrates that metformin, an established AMPK activator, significantly reduces the risk of colon cancer in patients with diabetes (15-17) and promotes the apoptosis of colon cancer cells (18). Therefore, the present study hypothesized that the botanical substance ginkgolic acid may inhibit the biological activity of colon cancer cells by activating the AMPK pathway. In the present study, SW480 human colon cancer cells were used as target cells to investigate the effects of ginkgolic acid on the clonal proliferation, migration and invasion of cancer cells in vitro, and to investigate potential molecular mechanisms. 


\section{Materials and methods}

Cell culture and reagents. Human colorectal cancer SW480 cells were purchased from the Institute of Biochemistry and Cell Biology Cell Bank (Shanghai Institutes for Biological Sciences, Chinese Academy of Sciences, Shanghai, China). Adherent SW480 cells were cultured in RPMI-1640 medium (Hyclone; GE Healthcare, Chicago, IL, USA) containing $10 \%$ fetal bovine serum (FBS, Hyclone; GE Healthcare), $100 \mu \mathrm{g} / \mathrm{ml}$ penicillin and $100 \mu \mathrm{g} / \mathrm{ml}$ streptomycin in a humidified incubator at $5 \% \mathrm{CO}_{2}$ and $37^{\circ} \mathrm{C}$ throughout the study. MTT, ginkgolic acid $\left(\mathrm{C} 15: 1 ; \mathrm{C}_{22} \mathrm{H}_{34} \mathrm{O}_{3}\right.$; molecular weight, 346.50), and dimethyl sulfoxide (DMSO) were purchased from Sigma-Aldrich; Merck KGaA (Darmstadt, Germany). Radioimmunoprecipitation assay protein lysis buffer was purchased from the Beyotime Institute of Biotechnology (Haimen, China). Information regarding the antibodies used in the present study is summarized in Table I. Ginkgolic acid was dissolved in methanol to prepare a $1 \mathrm{mmol} / \mathrm{l}$ stock solution, which was sterilized via filtration with a $0.22 \mu \mathrm{m}$ membrane filter (EMD Millipore, Billerica, MA, USA) and stored in the dark at $-20^{\circ} \mathrm{C}$. A working solution was diluted with RPMI-1640 immediately prior to use.

Cell proliferation assay. Tetrazolium dye-based MTT assays were performed to investigate the effect of ginkgolic acid on the proliferation of SW480 cells. SW480 cells in the exponential growth phase were harvested and seeded into 96-well plates at a density of $5 \times 10^{3}$ cells/well. Cells were starved with RPMI-1640 containing 1\% FBS overnight once they had adhered to plates. Next, cells were treated with different concentrations of ginkgolic acid $(0,5,10,20$ and $50 \mu \mathrm{mol} / \mathrm{l})$ or $25 \mathrm{mg} / \mathrm{l} 5-\mathrm{Fu}$ (5-FU concentration was chosen based on a previous in-house determination of the 5 -FU $\mathrm{IC}_{50}$, data not shown) and cultured for $12,24,36$ or $48 \mathrm{~h}$. A total of $20 \mu \mathrm{l}$ MTT solution $(5 \mathrm{mg} / \mathrm{ml})$ was added into each well, and the cells were incubated at $37^{\circ} \mathrm{C}$ for $4 \mathrm{~h}$. The supernatant was carefully aspirated and discarded, and $150 \mu \mathrm{l}$ of DMSO was added into each well. The plates were placed on a shaker for $15 \mathrm{~min}$, and the optical density (OD) at $490 \mathrm{~nm}$ was measured for each well on a microplate reader (Bio-Rad Laboratories, Hercules, CA, USA).

Wound-scratch assay. SW480 cells in the exponential growth phase were harvested, and the cell density was adjusted to $1 \times 10^{6}$ cells $/ \mathrm{ml} ; 500 \mu \mathrm{l}$ cell suspension was added into each well of 24-well plates, and the cells were cultured to $100 \%$ confluence. A $200-\mu 1$ sterile pipette tip was used to scratch the bottom of the wells, the medium was discarded and the wells were washed three times with sterile PBS to remove scratched cells. Next, serum-free medium containing $0 \mu \mathrm{mol} / 1$ (the control group) or $10 \mu \mathrm{mol} / 1$ ginkgolic acid was added, the plates were placed in an incubator at $37^{\circ} \mathrm{C}$ with $5 \% \mathrm{CO}_{2}$, and images (magnification, $\mathrm{x} 40$ ) of the same spot were captured at 0 and $36 \mathrm{~h}$ under an inverted microscope (Nikon Instruments Inc., Tokyo, Japan). Each group included 3 duplicates.

Matrigel-invasion assay. SW480 cells were treated with different concentrations $(0,10$ and $20 \mu \mathrm{mol} / \mathrm{l})$ of ginkgolic acid for $24 \mathrm{~h}$, harvested, centrifuged at $100 \mathrm{x} \mathrm{g}$ for $5 \mathrm{~min}$ at room temperature and resuspended in serum-free medium at $\sim 2.5 \times 10^{5}$ cells $/ \mathrm{ml}$. Matrigel-coated Transwell chambers were placed in 24 -well plates; $200 \mu \mathrm{l}$ cell suspension $\left(\sim 5.0 \times 10^{4}\right.$ cells $)$ was added into each well in the upper chamber, and $500 \mu \mathrm{l}$ medium containing $10 \%$ FBS was added to the lower chamber. Subsequent to incubation for $48 \mathrm{~h}$, the chamber was removed, the medium in the upper chamber was discarded and a cotton swab was used to wipe cells on the polycarbonate membrane that did not cross the membrane. Next, the chamber was stained with $0.5 \%$ crystal violet solution (prepared with $0.1 \%$ methanol) at room temperature for $30 \mathrm{~min}$, washed with tap water and observed under an inverted microscope (magnification, $\mathrm{x} 200$ ). The number of cells that migrated to the underside of the membrane was counted. The group treated with $0 \mu \mathrm{mol} / \mathrm{l}$ ginkgolic acid was used as the control group. A total of 10 fields of view were counted in each group, and the mean value was used for subsequent analysis. Each group included 3 duplicates, and the experiment was repeated 3 times.

Reverse transcription quantitative polymerase chain reaction $(R T-q P C R)$. Following treatment with different concentrations $(0,10$ and $20 \mu \mathrm{mol} / \mathrm{l})$ of ginkgolic acid for $24 \mathrm{~h}$, total RNA was extracted from the SW480 cells according to the protocol of the manufacturer of the RNA extraction kit (Thermo Fisher Scientific, Inc., Waltham, MA, USA). A total of $2 \mu \mathrm{l}$ RNA was used for cDNA synthesis with a reverse transcription kit (Takara Biotechnology Co., Ltd., Dalian, China). A total of $1 \mu 1$ reverse transcription reaction solution was used as the template in a $20 \mu$ l-reaction system for qPCR using a SYBR Green Real-time PCR Master Mix (Takara Biotechnology Co., Ltd., Dalian, China) on a Bio-Rad quantitative fluorescence PCR instrument (Bio-Rad Laboratories, Inc., Hercules, CA, USA). PCR thermocycler conditions were as follows: Heating at $94^{\circ} \mathrm{C}$ for $5 \mathrm{~min}$, followed by 40 cycles of denaturation at $94^{\circ} \mathrm{C}$ for $30 \mathrm{sec}$, annealing at $60^{\circ} \mathrm{C}$ for $30 \mathrm{sec}$ and extension at $72^{\circ} \mathrm{C}$ for $1 \mathrm{~min}$. Terminal extension was then performed at $72^{\circ} \mathrm{C}$ for $5 \mathrm{~min}$. $\beta$-actin was used as an internal control, and the relative expression levels of target genes were calculated using the $2^{-\triangle \Delta C q}$ method (19) using GAPDH as the normalization control. PCR primer sequences are presented in Table II.

RNA interference (RNAi). RNAi was used to knockdown AMPK expression in SW480 cells. AMPK-targeting small interfering (si)RNA sequences were designed and synthesized by Shanghai GenePharma Co., Ltd. (Shanghai, China). The sequences are included in Table III. SW480 cells were seeded into 6-well plates at $5.0 \times 10^{6}$ cells/well and were transfected with siRNA at $60-70 \%$ confluence. Lipofectamine ${ }^{\circledR} 2000$ (Thermo Fisher Scientific, Inc.) was used for transfection according to the manufacturer's protocol. Further experiments were performed at $24 \mathrm{~h}$ subsequent to transfection.

Western blot analysis. Western blotting was performed as previously described (20). Total protein was extracted from treated cells, and then the protein concentration was measured with the bicinchoninic acid (BCA) method. An equal amount of protein from each group was separated by SDS-PAGE and then transferred to a polyvinylidene fluoride membrane with a semi-dry method. The membrane was blocked in 5\% skimmed milk at room temperature for $2 \mathrm{~h}$ incubated with diluted primary 
Table I. Antibodies used in the present study.

\begin{tabular}{lccc}
\hline Antibody & Catalog number & Dilution & Company \\
\hline Rabbit anti-uPA & $17968-1-$ AP & $1: 500$ & ProteinTech Groups, Inc., Chicago, IL, USA \\
Rabbit anti-MMP-9 & $10375-2-A P$ & $1: 800$ & \\
Rabbit anti-MMP-2 & $10373-2-A P$ & $1: 800$ & \\
Rabbit anti-CXCR4 & ab2074 & $1: 1,000$ & Abcam, Cambridge, UK \\
Rabbit anti-AMPK & $\# 2532$ & $1: 800$ & Cell Signaling Technology, Inc., Danvers, MA, USA \\
Rabbit anti-p-AMPK & $\# 2535$ & $1: 1,000$ & \\
Mouse anti- - -actin & sc-47778 & $1: 2,000$ & Santa Cruz Biotechnology, Inc., Dallas, TX, USA \\
Goat anti-rabbit IgG-HRP & sc-2004 & $1: 10,000$ & \\
Goat anti-mouse IgG-HRP & sc-2005 & $1: 10,000$ & \\
\hline
\end{tabular}

uPA, urinary-type plasminogen activator; MMP, matrix metalloproteinase; CXCR4, C-X-C chemokine receptor 4; AMPK, adenosine 5'-monophosphate-activated protein kinase; $p$, phosphorylated; HRP, horseradish peroxidase.

Table II. Primers for quantitative polymerase chain reaction.

\begin{tabular}{|c|c|}
\hline Genes & Primer sequences \\
\hline \multirow[t]{2}{*}{ Adenosine 5'-monophosphate-activated protein kinase } & P1: 5'-GTAAGAATGGAAGGCTGGATGA-3 \\
\hline & P2: 5'-TCTGGTGCAGCATAGTTGGG-3' \\
\hline \multirow[t]{2}{*}{ Urinary-type plasminogen activator } & P1: 5'-TAAGATCTGGTGTCTGATTG-3' \\
\hline & P2: 5'-TTGGATGAACTAGGCTAAAA-3' \\
\hline \multirow[t]{2}{*}{ MMP-9 } & P1: 5'-GTGCTGGGCTGCTGCTTTGCTG-3' \\
\hline & P2: 5'-GTCGCCCTCAAAGGTTTGGAAT-3' \\
\hline \multirow[t]{2}{*}{ MMP-2 } & P1: 5'-GATGATGCCTTTGCTCGTGC-3' \\
\hline & P2: 5'-CAAAGGGGTATCCATCGCCA-3' \\
\hline \multirow[t]{2}{*}{$\mathrm{C}-\mathrm{X}-\mathrm{C}$ chemokine receptor 4} & P1: 5'-TCTGTGACCGCTTCTACC-3' \\
\hline & P2: 5'-AGGATGAGGATGACTGTGG-3' \\
\hline \multirow[t]{2}{*}{$\beta$-actin } & P1: 5'-CATCACTATCGGCAATGAGC-3' \\
\hline & P2: 5'-GACAGCACTGTGTTGGCATA-3' \\
\hline
\end{tabular}

MMP, matrix metalloproteinase; $\mathrm{P}$, forward primer; $\mathrm{P} 2$, reverse primer.

Table III. siRNA sequences for AMPK

\begin{tabular}{ll}
\hline siRNA name & \multicolumn{1}{c}{ siRNA sequences } \\
\hline si-AMPK\#1 & Sense: 5'-UUCUCCGAACGUGUCACGUTT-3' \\
si-AMPK\#2 & Antisense:5'-ACGUGACACGUUCGGAGAATT-3' \\
si-AMPK\#3 & Sense: 5'-GCGUGUACGAAGGAAGAAUTT-3' \\
si-Control & Antisense: 5'-AUUCUUCCUUCGUACACGCTT-3' \\
& Sense: 5'-CGGGAUCAGUUAGCAACUATT-3' \\
& Antisense:5'-UAGUUGCUAACUGAUCCCGTT-3' \\
\hline
\end{tabular}

siRNA, small interfering RNA; AMPK, adenosine 5'-monophosphate-activated protein kinase.

antibodies (Table I) at $4^{\circ} \mathrm{C}$ overnight, washed with TBST buffer, incubated with the secondary antibodies (dilution, 1:1,000;
Table I) at room temperature for $1 \mathrm{~h}$ and washed three times with TBST buffer. ECL chemiluminescence reagents (EMD 


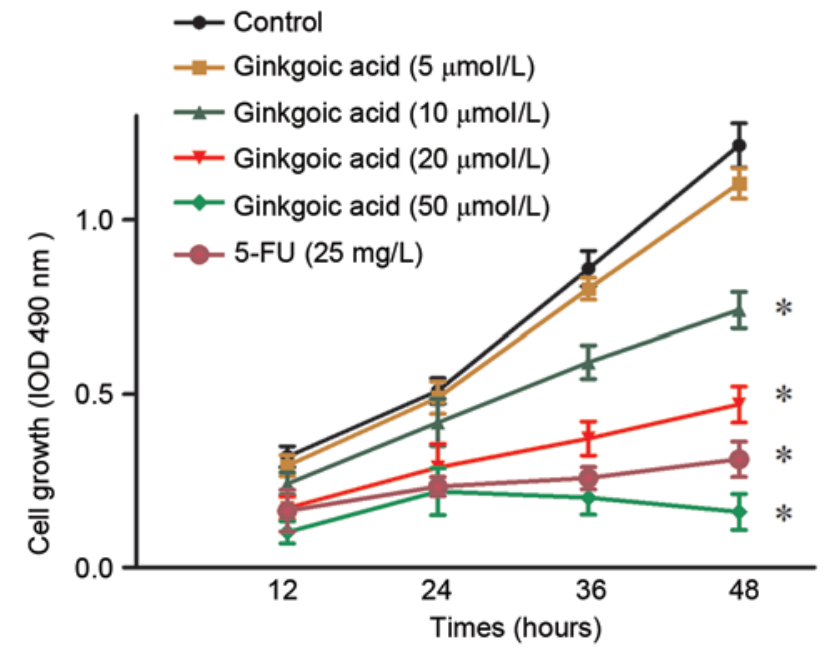

Figure 1. Effects of ginkgolic acid on the viability of SW480 cells. SW480 cells were treated with ginkgolic acid at various concentrations $(0,5,10,20$ and $50 \mu \mathrm{mol} / \mathrm{l})$. At the indicated time points $(12,24,36$ and $48 \mathrm{~h})$, cell viability in each group was assessed by an MTT assay. Cells treated with $0 \mu \mathrm{mol} / 1$ ginkgolic acid were used as a negative control group, and cells treated with $25 \mathrm{mg} / 15$-FU were a positive control group. Data are presented as the mean \pm standard deviation. ${ }^{*} \mathrm{P}<0.05$ vs. negative control. 5 -FU, fluorouracil.

Millipore, Billerica, MA, USA) were added, and images were captured with the ChemiDoc XRS imaging system (Bio-Rad Laboratories, Inc.). $\beta$-actin was used as an internal reference to calculate the relative expression level of the proteins.

Statistical analysis. Data were expressed as the mean \pm standard deviation. The SPSS 15.0 software package (SPSS, Inc., Chicago, IL, USA) was used for data analysis. One-way analysis of variance was performed to compare measurement data among the groups and post-hoc analysis of significant effects was performed using Dunnett's test. $\mathrm{P}<0.05$ was considered to indicate a statistically significant difference. Each experiment was repeated $\geq 3$ times.

\section{Results}

Effects of ginkgolic acid on the proliferation of SW480 colon cancer cells. In the present study, the effect of ginkgolic acid on the proliferation of SW480 colon cancer cells was initially investigated. SW480 cells were treated with different concentrations of ginkgolic acid $(5,10,20$ and $50 \mu \mathrm{mol} / 1)$. MTT assays were performed at different time points (12, 24, 36 and $48 \mathrm{~h}$ ). Cells treated with $0 \mu \mathrm{mol} / 1$ ginkgolic acid were used as the normal control group, and cells treated with $25 \mathrm{mg} / \mathrm{l}$ fluorouracil were used as a positive control. The results demonstrated ginkgolic acid treatment inhibited the proliferation of SW480 cells in a concentration- and time-dependent manner; a higher concentration of ginkgolic acid was associated with a greater extent of inhibition $(\mathrm{P}<0.05$ at 10,20 and $50 \mu \mathrm{mol} / 1$ compared with $0 \mu \mathrm{mol} / \mathrm{l})$. At $50 \mu \mathrm{mol} / 1$ ginkgolic acid, cell proliferation was almost completely inhibited. Therefore, 10 and $20 \mu \mathrm{mol} / \mathrm{l}$ ginkgolic acid were used for subsequent experiments (Fig. 1).

Effects of ginkgolic acid on the migration and invasion of SW480 colon cancer cells. Tumor cell migration and invasion are important processes in the relapse and metastasis of colon cancer. Therefore, the effects of ginkgolic acid on the migration and invasion of SW480 cells were investigated. Wound-healing assays were performed to investigate the effects of ginkgolic acid on the migration ability of SW480 cells. As demonstrated in Fig. 2A, $10 \mu \mathrm{mol} / 1$ ginkgolic acid significantly inhibited the migration of SW480 cells compared with the control group $(\mathrm{P}<0.05)$.

Transwell chamber assays were performed to investigate the effects of ginkgolic acid on the invasion ability of SW480 cells. As demonstrated in Fig. 2B, 10 and $20 \mu \mathrm{mol} / 1$ ginkgolic acid treatments significantly reduced the number of tumor cells that crossed the Transwell chamber $(\mathrm{P}<0.05)$; the invasion of SW480 cells was decreased to a greater extent at an increased dose of ginkgolic acid, suggesting that ginkgolic acid inhibited the invasion of SW480 cells in a concentration-dependent manner.

Ginkgolic acid inhibits the expression of invasion-associated proteins in SW480 colon cancer cells. The results of the aforementioned experiments suggest that ginkgolic acid significantly inhibited the proliferation, invasion and migration of SW480 colon cancer cells. Next, the effects of ginkgolic acid on the expression of invasion-associated genes [including matrix metalloproteinase (MMP)-2, MMP-9, urinary-type plasminogen activator (uPA), and C-X-C chemokine receptor type 4 (CXCR4) ] in SW480 cells were investigated. SW480 cells were treated with 10 or $20 \mu \mathrm{mol} / 1$ ginkgolic acid for $24 \mathrm{~h}$, and total mRNA was extracted for qPCR. As demonstrated by Fig. 3A, ginkgolic acid treatment significantly reduced the expression of MMP-2 and -9, uPA and CXCR4 mRNA in a concentration-dependent manner $(\mathrm{P}<0.05)$. Western blotting results were similar to the $\mathrm{qPCR}$ results (Fig. 3B); treatments with 10 and $20 \mu \mathrm{mol} / 1$ ginkgolic acid inhibited the expression of invasion-associated proteins, including MMP-2 and -9, uPA, and CXCR4. These results suggested that ginkgolic acid downregulated the expression of invasion-associated molecules in SW480 cells at transcriptional and post-transcriptional levels.

Activation of AMPK is associated with the ginkgolic acid regulation of invasion-associated molecules. A previous study indicated that inducing AMPK activation may be an important mechanism for the antitumor effects of ginkgolic acid (1). Therefore, the effect of ginkgolic acid on AMPK expression and activation in SW480 cells was investigated. Fig. 4A demonstrates that ginkgolic acid exhibited no significant effect on AMPK protein expression in SW480 cells; however, ginkgolic acid significantly increased the expression of phosphorylated AMPK (p-AMPK), suggesting that ginkgolic acid induced AMPK activation in SW480 cells. To investigate whether AMPK mediated the downregulation of invasion-associated molecules by ginkgolic acid in SW480 colon cancer cells, AMPK-targeting siRNAs were designed and verified by qPCR and western blotting. Fig. 4B and C indicate that all three siRNAs silenced AMPK expression at the mRNA and protein levels, particularly si-AMPK\#1. Therefore, following AMPK silencing with si-AMPK\#1, SW480 colon cancer cells were treated with ginkgolic acid for $48 \mathrm{~h}$ and western blotting was performed to detect the expression of invasion-associated 
A
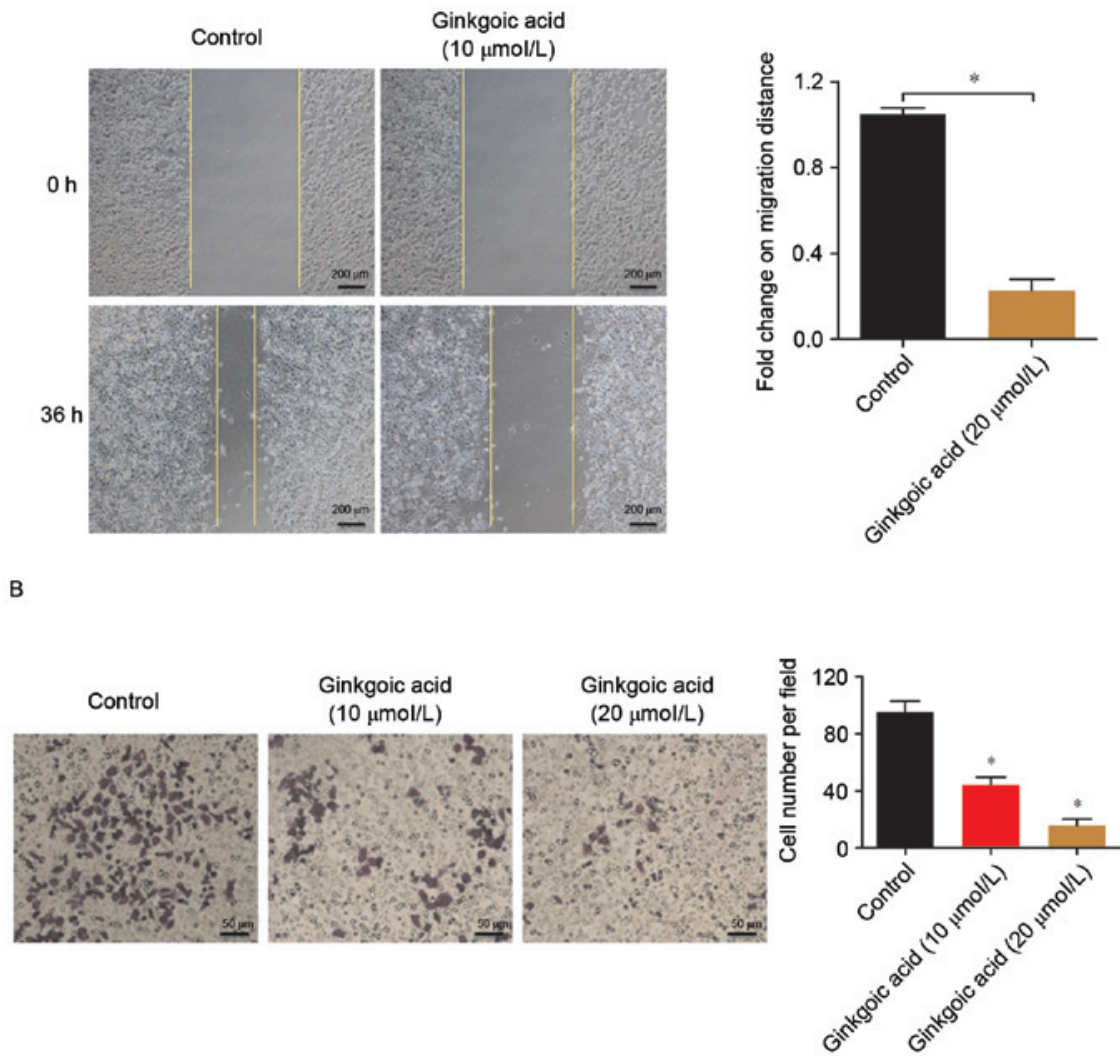

Figure 2. Effects of ginkgolic acid on the migration and invasion of SW480 cells. (A) SW480 cells at $90 \%$ confluence were treated with $10 \mu \mathrm{M}$ ginkgolic acid or vehicle for $12 \mathrm{~h}$, and a scratch assay was performed. Images were captured at 0 and $36 \mathrm{~h}$ at x40 magnification. "P<0.05. (B) SW480 cells were seeded into a Matrigel-coated invasion chamber subsequent to treatment with ginkgolic acid at various concentrations $(0,10$ and $20 \mu$ mol/l), and a Matrigel-invasion assay was performed at $48 \mathrm{~h}$. The number of invaded cells was quantified by counting the cells from 10 random fields at x 20 magnification. Data are presented as the mean \pm standard deviation. ${ }^{*} \mathrm{P}<0.05$ vs. control.

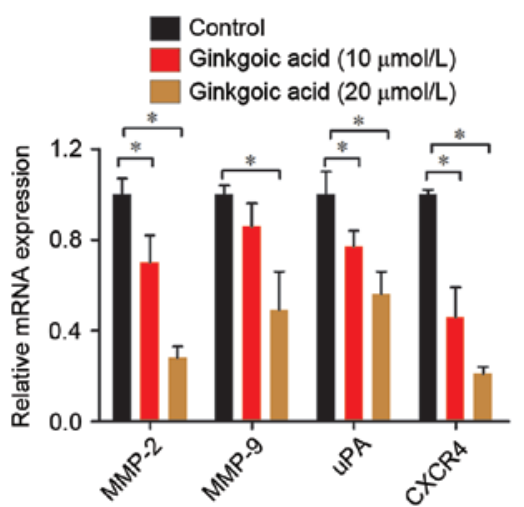

B

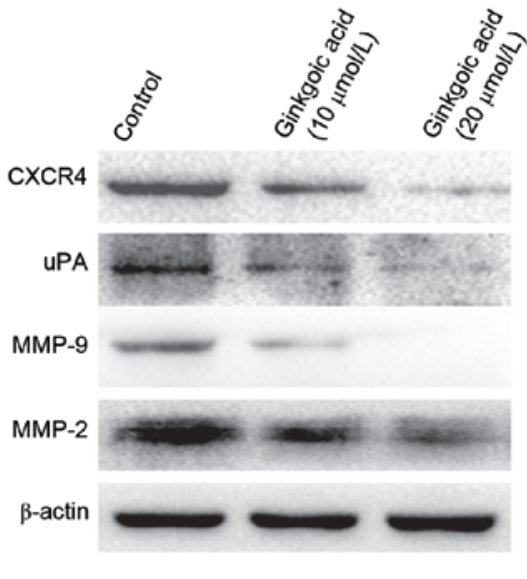

Figure 3. Ginkgolic acid suppresses the expression of invasion-associated genes and proteins. (A) SW480 cells were treated with ginkgolic acid at various concentrations $(0,10$ and $20 \mu \mathrm{mol} / \mathrm{l})$ for $24 \mathrm{~h}$, and the mRNA levels of invasion-associated markers (MMP-2 and -9 , uPA and CXCR4) were measured by reverse transcription-quantitative polymerase chain reaction. The expression of each target gene was quantified using $\beta$-actin as a normalization control. Data are presented as the mean \pm standard deviation. ${ }^{*} \mathrm{P}<0.05$. (B) The protein levels of invasion-associated markers were measured by western blotting following ginkgolic acid treatment for $48 \mathrm{~h}$. MMP, matrix metalloproteinase; uPA, urinary-type plasminogen activator; CXCR4, C-X-C chemokine receptor 4.

proteins. Fig. 4D demonstrates that AMPK knockdown alone exhibited no significant effect on the expression of MMP-2, uPA, or CXCR4 in SW480 cells; however, it removed the inhibitory effect of ginkgolic acid on the expression of MMP-2, uPA, and CXCR4.
The invasion ability of SW480 cells was determined by a matrigel-invasion assay following siRNA knockdown of AMPK and ginkgolic acid treatment. As indicated in Fig. 4E, the invasion ability of SW480 cells was impaired by ginkgolic acid treatment. However, this effect of was partially restored 


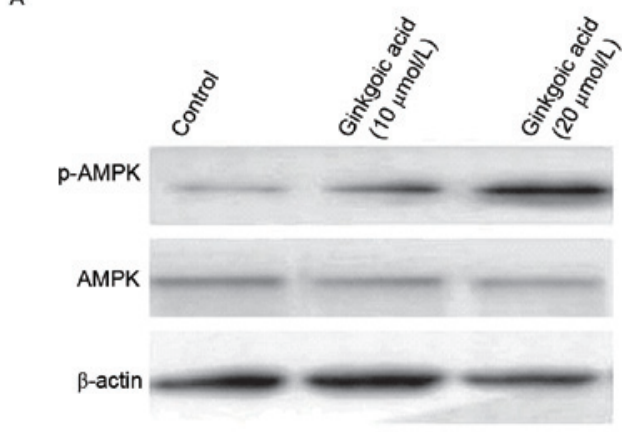

c

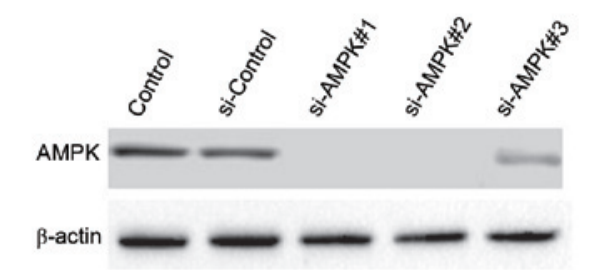

E

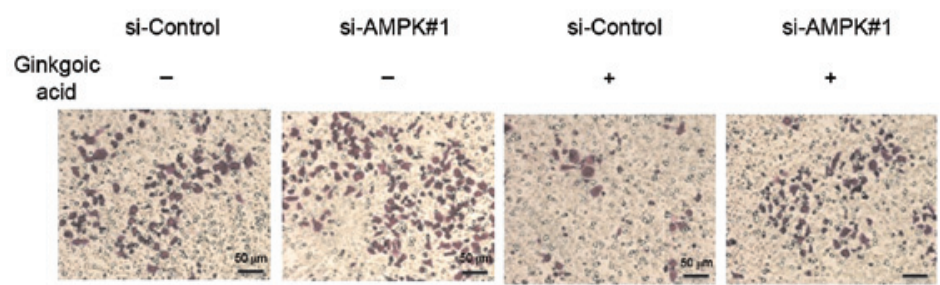

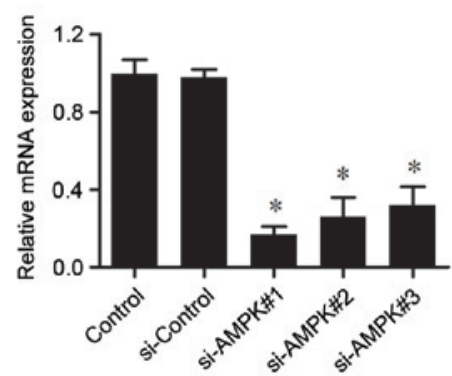

D

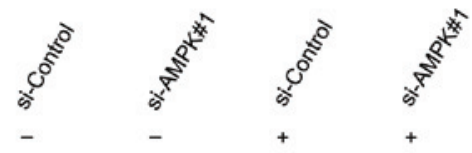

(20 $\mu \mathrm{mol} / \mathrm{L})$

CXCR4

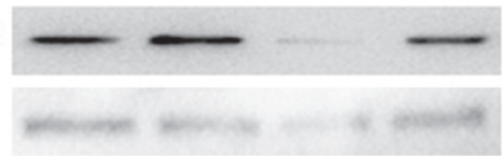

MPA

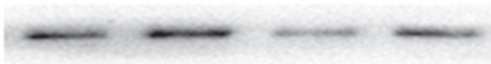

p-AMPK

$\beta$-actin

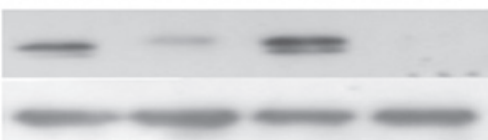

Figure 4. Ginkgolic acid-mediated downregulation of invasion-associated molecules in SW480 cells is associated with the activation of AMPK. (A) The expression of AMPK and p-AMPK in SW480 cells following ginkgolic acid treatment were detected by western blotting. siRNAs were used to silence AMPK expression in SW480 cells. The efficiency of siRNAs targeting AMPK was evaluated by (B) reverse transcription-quantitative polymerase chain reaction and (C) western blotting. (D) SW480 cells were treated with ginkgolic acid ( $20 \mu \mathrm{mol} / \mathrm{l})$ for $48 \mathrm{~h}$ following AMPK silencing, and the expression of MMP-2, uPA, CXCR4 and p-AMPK were detected by western blotting. (E) The invasive ability of SW480 cells was detected by a matrigel-invasion assay following siRNA knockdown of AMPK with ginkgolic acid treatment. The number of invaded cells was quantified by counting the cells from 10 random fields at x 200 magnification. Data are presented as the mean \pm standard deviation. ${ }^{*} \mathrm{P}<0.05$. AMPK, adenosine 5'-monophosphate-activated protein kinase; $\mathrm{p}-$, phosphorylated; siRNA, small interfering RNA; MMP, matrix metalloproteinase; uPA, urinary-type plasminogen activator; CXCR4, C-X-C chemokine receptor 4.

by AMPK knockdown. These results suggest that ginkgolic acid may inhibit the invasion ability of SW480 colon cancer cells via AMPK signaling.

\section{Discussion}

Tumor relapse and metastasis are the leading causes of mortality in patients with colorectal cancer (21). At present, surgery remains the primary treatment for colorectal cancer, although preoperative and postoperative adjuvant chemotherapy have improved the survival rate for patients with medium-stage and advanced colorectal cancer. Chemotherapy may reduce the size of the primary tumor and reduces postoperative metastasis and relapse. Currently, a range of chemotherapy drugs is in use, although drugs are rarely effective without inducing significant adverse reactions (6-7). A number of natural active plant-based compounds have demonstrated preventive effects and have been suggested to inhibit tumor growth.

Ginkgolic acid, a phenolic acid extracted from the ginkgo tree, has been demonstrated to possess significant anti-inflammatory, anti-viral, and antibacterial $(22,23)$. Its antitumor properties have attracted a great deal of attention $(24,25)$, but the detailed mechanisms are unknown. A previous study has revealed that ginkgolic acid inhibits the proliferation, invasion, migration and colony-forming ability of pancreatic cancer cells with minimal toxicity to normal cell lines, even at high concentrations (11). Its mechanism of action may involve AMPK activation and the inhibition of downstream 
lipid synthesis (11). Zhou et al (12) indicated that ginkgolic acid induced cell cycle arrest and regulated the expression of apoptosis-associated proteins, thereby inhibiting tumor growth and inducing apoptosis. The present study demonstrated that ginkgolic acid inhibited the growth of SW480 colon cancer cells in a concentration-dependent manner and reduced cell proliferation and migration, most likely by inducing AMPK activation. These results suggest that ginkgolic acid exhibits antitumor effects and is a promising, safe and effective drug for colorectal cancer.

The chemokine receptor CXCR4 is a type of G-protein coupled receptor. It binds to the corresponding ligand to exert a number of biological effects, including promoting tumor proliferation, growth, invasion and metastasis (26). Previous studies have suggested that CXCR4 is expressed at different levels in the majority of colorectal cancer cell lines and cancer tissues, whereas it is almost non-existent in normal tissues $(27,28)$. Studies have revealed that CXCR4 and its ligand SDF-1 are highly expressed in lymph node and liver metastases of colorectal cancer, and that this expression is closely associated with cancer progression (29-33). In a mouse model for colorectal cancer metastasis, CXCR4 served a critical role in maintaining the proliferation of tumor cells in colorectal cancer metastases (34). AMD3100, a specific CXCR4 inhibitor, significantly reduced colorectal cancer liver metastasis in mice (35). These results suggest that CXCR4 may serve a crucial role in colorectal cancer progression, particularly in invasion and metastasis. The present study indicated that ginkgolic acid inhibited the invasion and migration of SW480 cells; particularly, ginkgolic acid inhibited the expression of CXCR4 in SW480 cells.

AMPK, a serine/threonine protein kinase complex, is an intracellular energy sensor. Activated AMPK is associated with tumor growth and proliferation, cell cycle progression, apoptosis, angiogenesis, and tumor invasion and metastasis (36). Epidemiological data indicate that metformin, an AMPK agonist, reduces the morbidity and mortality of patients with gastrointestinal tumors (37). AMPK may represent a novel target for antitumor treatment; however, its mechanism is complex and remains uncharacterized. At present, it is hypothesized that the activated AMPK pathway may exert antitumor effects by the following methods: i) Regulating key enzymes for lipid metabolism, including HMG-CoA reductase, aminocyclopropane-1-carboxylate (ACC) and fatty acid synthase (FASN), thereby inhibiting lipid synthesis and promoting lipid degradation in tumor cells; ii) acting on the mammalian target of rapamycin pathway, thereby directly inhibiting tumor proliferation and inducing cell cycle arrest and apoptosis; iii) indirectly inhibiting tumor invasion, metastasis and angiogenesis, thereby inhibiting tumor proliferation and preventing tumor progression; and iv) acting through other mechanisms, including downregulating the expression of cyclooxygenase 2 and regulating autophagy (38). Taken together, AMPK may be an important molecule for targeted therapy in gastrointestinal tumors.

In conclusion, the present study indicated that ginkgolic acid effectively inhibited the proliferation, invasion and migration of SW480 colon cancer cells and reduced the expression of invasion-associated proteins such as MMP-2, CXCR4 and uPA, likely mediated by inducing AMPK activation. In vivo experiments are required to validate the results. These results suggest that ginkgolic acid, a plant-based compound, may be an effective drug for colon cancer.

\section{Acknowledgements}

The present study was supported by the National Natural Science Foundation of China (grant no., 81572734), the Scientific and Technological Development Research Project Foundation by Shaanxi Province (grant nos. 2016SF-121 and 2016FS-141) and the Fundamental Research Funds for the Central Universities in Xi'an Jiaotong University.

\section{References}

1. Ferlay J, Shin HR, Bray F, Forman D, Mathers C and Parkin DM: Estimates of worldwide burden of cancer in 2008: GLOBOCAN 2008. Int J Cancer 127: 2893-2917, 2010.

2. Siegel RL, Miller KD and Jemal A: Cancer statistics, 2016. CA Cancer J Clin 66: 7-30, 2016.

3. Sung JJ, Ng SC, Chan FK, Chiu HM, Kim HS, Matsuda T, Ng SS, Lau JY, Zheng S, Adler S, et al: An updated Asia Pacific Consensus Recommendations on colorectal cancer screening. Gut 64: 121-132, 2015.

4. Abad A, Massuti B, Antón A, Vega ME, Yuste AL, Marcuello E, Manzano JL, Alonso V, Carrato A, Martinez-Villacampa M, et al: Colorectal cancer metastasis resectability after treatment with the combination of oxaliplatin, irinotecan and 5-fluorouracil. Final results of a phase II study. Acta Oncol 47: 286-292, 2008.

5. Abdel-Misih SR, Schmidt CR and Bloomston PM: Update and review of the multidisciplinary management of stage IV colorectal cancer with liver metastases. World J Surg Oncol 7: $72,2009$.

6. Brandi G, De Lorenzo S, Nannini M, Curti S, Ottone M, Dall'Olio FG, Barbera MA, Pantaleo MA and Biasco G: Adjuvant chemotherapy for resected colorectal cancer metastases: Literature review and meta-analysis. World J Gastroenterol 22: 519-533, 2016.

7. Yu QQ, Qiu H, Zhang MS, Hu GY, Liu B, Huang L, Liao X, Li QX, Li ZH and Yuan XL: Predictive effects of bilirubin on response of colorectal cancer to irinotecan-based chemotherapy. World J Gastroenterol 22: 4250-4258, 2016.

8. Major RT: The ginkgo, the most ancient living tree. The resistance of Ginkgo biloba L. To pests accounts in part for the longevity of this species. Science 157: 1270-1273, 1967.

9. van Beek TA and Wintermans MS: Preparative isolation and dual column high-performance liquid chromatography of ginkgolic acids from Ginkgo biloba. J Chromatogr A 930: 109-117, 2001.

10. Yang XM, Wang YF, Li YY and Ma HL: Thermal stability of ginkgolic acids from Ginkgo biloba and the effects of ginkgol C17:1 on the apoptosis and migration of SMMC7721 cells. Fitoterapia 98: 66-76, 2014.

11. Ma J, Duan W, Han S, Lei J, Xu Q, Chen X, Jiang Z, Nan L, Li J, Chen K, et al: Ginkgolic acid suppresses the development of pancreatic cancer by inhibiting pathways driving lipogenesis. Oncotarget 6: 20993-21003, 2015.

12. Zhou C, Li X, Du W, Feng Y, Kong X, Li Y, Xiao L and Zhang P: Antitumor effects of ginkgolic acid in human cancer cell occur via cell cycle arrest and decrease the Bcl-2/Bax ratio to induce apoptosis. Chemotherapy 56: 393-402, 2010.

13. Shilpa P, Kaveri K and Salimath BP: Anti-metastatic action of anacardic acid targets VEGF-induced signalling pathways in epithelial to mesenchymal transition. Drug Discov Ther 9: 53-65, 2015.

14. Zaha VG and Young LH: AMP-activated protein kinase regulation and biological actions in the heart. Circ Res 111: 800-814, 2012.

15. Evans JM, Donnelly LA, Emslie-Smith AM, Alessi DR and Morris AD: Metformin and reduced risk of cancer in diabetic patients. BMJ 330: 1304-1305, 2005.

16. Decensi A, Puntoni M, Goodwin P, Cazzaniga M, Gennari A, Bonanni B and Gandini S: Metformin and cancer risk in diabetic patients: A systematic review and meta-analysis. Cancer Prev Res (Phila) 3: 1451-1461, 2010.

17. Ioannou GN and Boyko EJ: Metformin and colorectal cancer risk in diabetic patients. Diabetes Care 34: 2336-2337, 2011. 
18. Montales MT, Simmen RC, Ferreira ES, Neves VA and Simmen FA: Metformin and soybean-derived bioactive molecules attenuate the expansion of stem cell-like epithelial subpopulation and confer apoptotic sensitivity in human colon cancer cells. Genes Nutr 10: 49, 2015.

19. Schmittgen TD and Livak KJ: Analyzing real-time PCR data by the comparative C(T) method. Nat Protoc 3: 1101-1108, 2008.

20. Li X, Ma Q, Xu Q, Liu H, Lei J, Duan W, Bhat K, Wang F, Wu E and Wang Z: SDF-1/CXCR4 signaling induces pancreatic cancer cell invasion and epithelial-mesenchymal transition in vitro through non-canonical activation of Hedgehog pathway. Cancer Lett 322: 169-176, 2012.

21. Smith JJ, Deane NG, Wu F, Merchant NB, Zhang B, Jiang A, Lu P, Johnson JC, Schmidt C, Bailey CE, et al: Experimentally derived metastasis gene expression profile predicts recurrence and death in patients with colon cancer. Gastroenterology 138: 958-968, 2010.

22. Lü JM, Yan S, Jamaluddin S, Weakley SM, Liang Z, Siwak EB Yao Q and Chen C: Ginkgolic acid inhibits HIV protease activity and HIV infection in vitro. Med Sci Monit 18: BR293-BR298, 2012

23. Lee JH, Kim YG, Ryu SY, Cho MH and Lee J: Ginkgolic acids and Ginkgo biloba extract inhibit Escherichia coli O157: $\mathrm{H} 7$ and Staphylococcus aureus biofilm formation. Int J Food Microbiol 174: 47-55, 2014.

24. Fukuda I, Ito A, Hirai G, Nishimura S, Kawasaki H, Saitoh H, Kimura K, Sodeoka M and Yoshida M: Ginkgolic acid inhibits protein SUMOylation by blocking formation of the E1-SUMO intermediate. Chem Biol 16: 133-140, 2009.

25. Oh J, Hwang IH, Hong CE, Lyu SY and Na M: Inhibition of fatty acid synthase by ginkgolic acids from the leaves of Ginkgo biloba and their cytotoxic activity. J Enzyme Inhib Med Chem 28: 565-568, 2013

26. Guo F, Wang Y, Liu J, Mok SC, Xue F and Zhang W: CXCL12/CXCR4: A symbiotic bridge linking cancer cells and their stromal neighbors in oncogenic communication networks. Oncogene 35: 816-826, 2016

27. Kim J, Takeuchi H, Lam ST, Turner RR, Wang HJ, Kuo C, Foshag L, Bilchik AJ and Hoon DS: Chemokine receptor CXCR4 expression in colorectal cancer patients increases the risk for recurrence and for poor survival. J Clin Oncol 23: 2744-2753, 2005.

28. Kim J, Mori T, Chen SL, Amersi FF, Martinez SR, Kuo C, Turner RR, Ye X, Bilchik AJ, Morton DL and Hoon DS: Chemokine receptor CXCR4 expression in patients with melanoma and colorectal cancer liver metastases and the association with disease outcome. Ann Surg 244: 113-120, 2006.
29. Murakami T, Kawada K, Iwamoto M, Akagami M, Hida K, Nakanishi Y, Kanda K, Kawada M, Seno H, Taketo MM and Sakai Y: The role of CXCR3 and CXCR4 in colorectal cancer metastasis. Int J Cancer 132: 276-287, 2013.

30. Schimanski CC, Schwald S, Simiantonaki N, Jayasinghe C, Gönner U, Wilsberg V, Junginger T, Berger MR, Galle PR and Moehler M: Effect of chemokine receptors CXCR4 and CCR7 on the metastatic behavior of human colorectal cancer. Clin Cancer Res 11: 1743-1750, 2005.

31. Brand S, Dambacher J, Beigel F, Olszak T, Diebold J, Otte JM, Göke B and Eichhorst ST: CXCR4 and CXCL12 are inversely expressed in colorectal cancer cells and modulate cancer cell migration, invasion and MMP-9 activation. Exp Cell Res 310: 117-130, 2005.

32. Sakai N, Yoshidome H, Shida T, Kimura F, Shimizu H, Ohtsuka M, Takeuchi D, Sakakibara M and Miyazaki M: CXCR4/CXCL12 expression profile is associated with tumor microenvironment and clinical outcome of liver metastases of colorectal cancer. Clin Exp Metastasis 29: 101-110, 2012.

33. Lv S, Yang Y, Kwon S, Han M, Zhao F, Kang H, Dai C and Wang R: The association of CXCR4 expression with prognosis and clinicopathological indicators in colorectal carcinoma patients: A meta-analysis. Histopathology 64: 701-712, 2014.

34. Abedini F, Ismail M, Hosseinkhani H, Ibrahim TA, Omar AR, Chong PP, Bejo MH and Domb AJ: Effects of CXCR4 siRNA/dextran-spermine nanoparticles on CXCR4 expression and serum LDH levels in a mouse model of colorectal cancer metastasis to the liver. Cancer Manag Res 3: 301-309, 2011.

35. Li JK, Yu L, Shen Y,Zhou LS, Wang YC and Zhang JH: Inhibition of CXCR4 activity with AMD3100 decreases invasion of human colorectal cancer cells in vitro. World J Gastroenterol 14: 2308-2313, 2008

36. Kuhajda FP: AMP-activated protein kinase and human cancer: Cancer metabolism revisited. Int J Obes (Lond) 32 (Suppl 4): S36-S41, 2008

37. Baur DM, Klotsche J, Hamnvik OP, Sievers C, Pieper L, Wittchen HU, Stalla GK, Schmid RM, Kales SN and Mantzoros CS: Type 2 diabetes mellitus and medications for type 2 diabetes mellitus are associated with risk for and mortality from cancer in a German primary care cohort. Metabolism 60: 1363-1371, 2011.

38. Aljada A and Mousa SA: Metformin and neoplasia: Implications and indications. Pharmacol Ther 133: 108-115, 2012. 